\title{
On the 'Squamulae Intravaginales' of the Helobieae.
}

\author{
BY \\ AGNES ARBER, D.SC., F.L.S. \\ (Keddey Fletcher-Warr Student of the University of London).
}

With five Figures in the Text.

(i) INTRODUCTION.

T $\mathrm{T}$ has long been known that certain scale-like structures, to which the 1 name squamulae intravaginales, or squamulae intraaxillares, was given by Irmisch, are found among the leaf-bases of the Helobieae (Potamogetonaceae, Naiadaceae, Aponogetonaceae, Scheuchzeriaceae, Alismataceae, Butomaceae, Hydrocharitaceae) and of certain members of the related family, Araceae. The earliest published record of the existence of these squamules seems to be that of Nolte (16), who, nearly a century ago, observed them in Stratiotes. But we owe the first comprehensive treatment of the subject to Irmisch (10), who published a paper in I 858 , which, though brief and unillustrated, laid the foundation of our knowledge of the structures in question; he also carried his observations further in other papers $(11,12,13,14)$. Caspary (5), Prillieux (17), Sanio (18), Bornet (2), Bayley Balfour (1), Buchenau (3 and 4), T. G. Hill (9), Fauth (7), Harvey Gibson (8), Serguéeff (21), Cunnington (6), and Solereder (22) have added further information about the morphology and distribution of the squamules. There are many good illustrations of their external appearance, both in the papers just cited-especially that of Bornet (2)-and in Kirchner, Loew, and Schröter's 'Lebensgeschichte der Blütenpflanzen Mitteleuropas'(15). Schilling (20), who has studied the squamules from the point of view of function, regards them as organs which secrete mucilage, but, according to Solereder (22), this does not hold good universally.

The number of squamules found in association with each leaf may range in different species from two to many; each of the squamules may either consist of a single plate of cells, or it may be a comparatively solid body, in which the upper and lower epidermis are separated by several

[Annals of Botany, Vol. XXXVII. No. CXLV. January, 1923.] 


\section{Arber.-On the 'Squamulae Intravaginales' of the Helobieae.}

elements. There is great variety in shape, and the appearance may be modified by a fringe of marginal hairs. But, despite this astonishing range of variation as regards number, form, and structure, the squamules all agree in the lack of vascular tissue, and in being apparently of a trichome nature.

Although we possess such a large amount of information about these squamules, the literature often reveals a certain vagueness on the practical question of their exact point of origin, and on the theoretical question of their morphological interpretation. They have generally been spoken of as 'intravaginal' or 'intra-axillary', or as occurring ' at the leaf-base', except in certain cases in which they have been observed to take their origin from the axis. Caspary (5), in 1858 , called them stipulae intrafoliaceae, while Prillieux (17), in I864, described them as very small stipules, and in more recent times Buchenau (4) has suggested that in the Alismataceae they should be regarded as 'Ligulargebilde'. Bornet (2) treated them as appendages of the leaf above them on the axis, while Irmisch and apparently all the other writers who have considered the squamules hold them to belong to the leaf below them, in regard to which they occupy a more or less axillary position. That some obscurity and uncertainty should exist on these points is not, however, surprising, since the greater part of the work on the subject predates the general employment of the microtome in botany; and, without serial sections, one could scarcely hope to arrive at a complete understanding of the relations between these minute and delicate squamules and the rest of the shoot. The object of the present paper is, with the help of the microtome, to trace the history of the development of the squamulae intravaginales in a small number of cases from among the Helobieae, in order to, see if it be possible in this way to obtain a firmer basis for the interpretation of these structures.

I am indebted to Professor Ostenfeld, of Copenhagen, for: material of Cymodocea isoëtifolia, Asch.

\section{(ii) Description OF OBSERVATIONS.}

\section{Potamogetonaceae-Potamogeton.}

Fig. I A gives a general idea of the appearance of the squamules among the leaves, as they are seen in a transverse section of the inner part of an apical bud belonging to a broad-leaved, submerged species of Potamogeton (unidentified). In the case of the outermost leaf represented, only the ligular sheath (lig. $s_{\cdot 1}$ ) is included; a large number of squamules $(s q . a)$ are seen between it and the next leaf. One of these squamules-that indicated by an arrow in Fig. I A-is shown on a larger scale in Fig. I B. The leaf inside this set of squamules is cut through the base of its limb (lam..$_{2}$ ) and ligular sheath $\left(l i g \cdot s_{._{2}}\right)$, on the inner side of which another set of squamules $(s q . b)$ 
are seen. A still younger leaf (pet..$_{3}$ and lig. $s_{3}$ ) has further squamules $(s q . c)$ within it, surrounding the developing apex (ap.). In Figs. I C and $\mathrm{D}$, the changes which are passed through by this growing-point, between the level of Fig. $1 \mathrm{~A}$ and the tip of the shoot, can be followed. Fig. I C shows another leaf $\left(l_{\cdot_{4}}\right)$ and a further set of squamules $(s q . d)$, while in Fig. I D

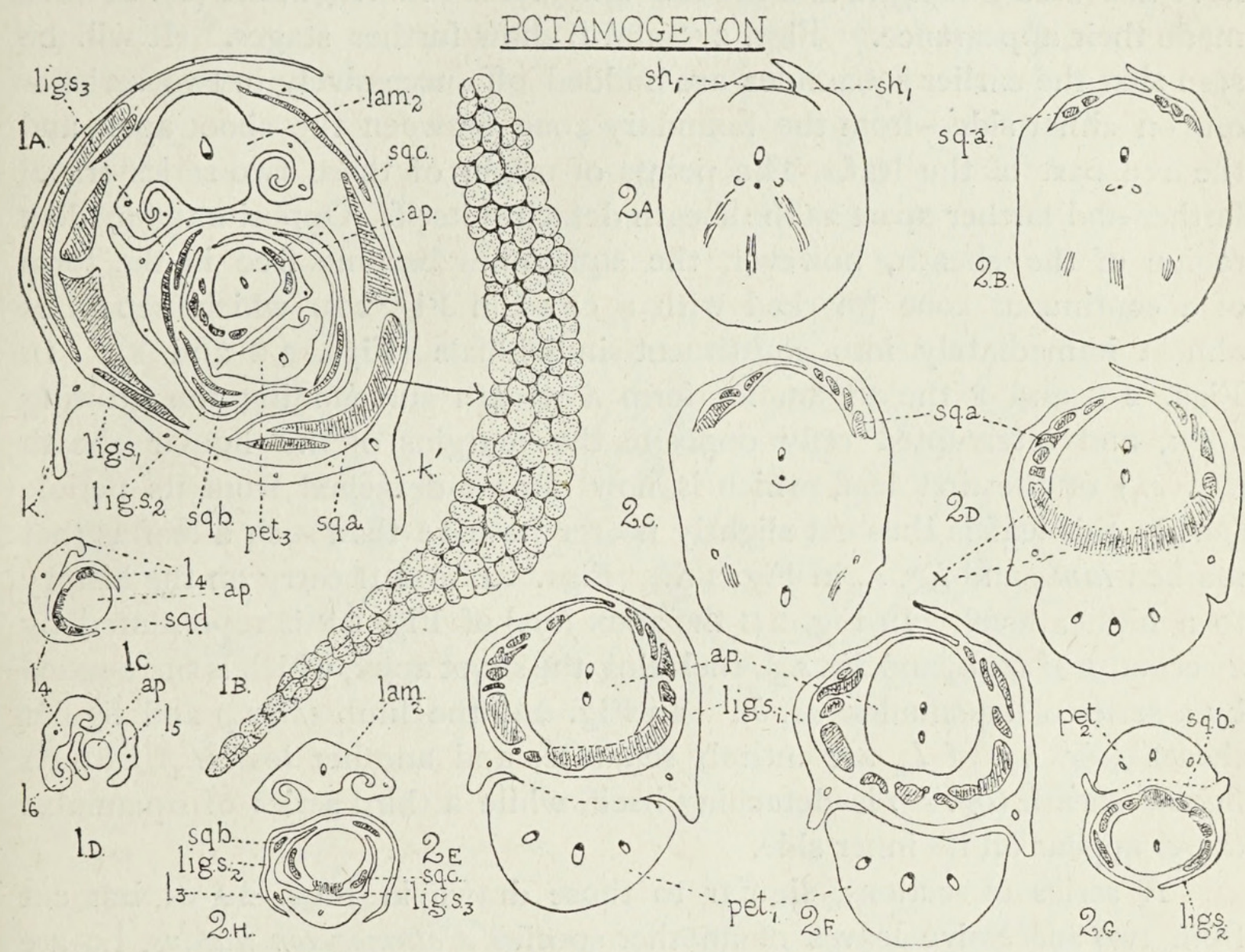

FIgs. I and 2. Potamogeton sp. (broad-leaved, submerged fornı). Fig. I A, transverse section of inner part of apical bud $(x 47)$; in case of outermost leaf represented, only the ligular sheath $\left(\right.$ lig. s.1) with its keels $\left(k\right.$. and $k^{\prime}$.) are shown; limb $\left(\operatorname{lam}_{._{2}}\right)$ and ligular sheath (lig. s..$\left._{2}\right)$ of second leaf; petiole or base of limb (pet. .3$)$ and sheath (lig. $\left.s_{\cdot 3}\right)$ of third leaf; ap., shoot-apex. Three sets of squamules (shaded), sq. $a, s q . b, s q . c$, are seen outside second leaf, third leaf, and apex respectively. Fig. I B, transverse section of squamule marked with arrow in Fig. I A ( X I 93). Figs. I C and D, changes in shoot apex ( $a p$. of Fig. I A) as tip is approached $(\times 47)$. Fig. I C, fourth leaf $(l .4)$ detaching itself from apex, and squamules $(s q . d)$ occurring between it and apex. Fig. I D is close to tip of shoot, and shows highest leaves $\left(l_{._{5}}\right.$ and $\left.l_{._{6}}\right)$ on either side of apex $(a p$.$) . Figs. 2 \mathrm{~A}-\mathrm{H}$, series of transverse sections from below upwards through three successive young leaves and growingpoint of another bud $(x 47)$; sections broken on side towards petiole of leaf $\mathrm{r}$, so this region reconstructed; lettering as in Fig. I; $s h_{1}$ and $s h^{\prime}{ }_{1}$, margins of sheathing leaf-base.

the extreme apex of the axis is reached $(a p$.$) , lying between the two$ youngest leaves $\left(l_{._{5}}\right.$ and $\left.l_{._{6}}\right)$. The set of squamules within leaf 4 in Fig. I C are the youngest to be found in this shoot; I cannot with certainty detect any inside leaf 5 or leaf 6.

The sections drawn in Figs. I A-D are too far above the bases of most of the leaves to give much enlightenment on the origin of the squamules: for this we must turn to Figs. $2 \mathrm{~A}-\mathrm{H}$, which represent sections from a series 
passing from below upwards through the basal regions of three successive leaves belonging to another apical bud. In Fig. $2 \mathrm{~A}$ the first of these leaves is just beginning to detach itself from the growing apex; the earliest sign of this detachment is the appearance of the two free overlapping margins of the sheathing leaf-base $\left(s h_{._{1}}\right.$ and $\left.s h_{{ }_{1}}{ }_{1}\right)$. In Fig. 2 B the free flaps of leaf tissue have increased in length, and the first squamulae intravaginales $(s q . a)$ have made their appearance. Figs. $2 \mathrm{C}$ and $\mathrm{D}$ show further stages. It will be seen that the earlier squamules are budded off successively in two seriesone on either side-from the boundary zone between the shoot apex and the free part of the leaf. The points of origin of these two series travel farther and farther apart as the sheath detaches itself. Opposite the median region of the sheath, however, the squamules become free in the form of a continuous zone (marked with a cross in Fig. $2 \mathrm{D}$ ) which separates almost immediately into constituent individuals (Figs. $2 \mathrm{E}$ and $\mathrm{F}$ ). In Figs. $2 \mathrm{E}$ and $\mathrm{F}$ the squamules form a wreath surrounding the growing apex, and interrupted only opposite the margins of the ligular sheath (lig. $s_{\cdot_{1}}$ ) of the first leaf, which is now almost detached from its petiole $\left(\right.$ pet. $\left._{1}\right)$; this leaf is thus cut slightly nearer its base than such a leaf as that marked lam., and lig. s..$_{2}$ in Fig. I A. Figs. $2 \mathrm{G}$ and $\mathrm{H}$ carry on the history to a higher level. In Fig. $2 \mathrm{G}$ the apex $(a p$.$) of Fig. 2 \mathrm{~F}$ is represented by a second leaf (pet..$_{2}$ and lig..$_{._{2}}$ ), enclosing the shoot apex, which is surrounded by a series of squamules $(s q . b)$. In Fig. $2 \mathrm{H}$ the limb $\left(\operatorname{lam}_{._{2}}\right)$ and ligular sheath ( $\left(i g . s_{._{2}}\right.$ ) of $l_{._{2}}$ are entirely separate, and another leaf $\left(l_{\cdot_{3}}\right)$ with its ligular sheath (lig. s..$_{3}$ ) is detaching itself, while a third series of squamulae (sq. c) appear on its inner side.

A series of sections, similar to those drawn in Figs. $2 \mathrm{~A}-\mathrm{H}$, but cut from two successive leaves of another species, Potamogeton natans, L., are seen in Figs. 3A-G. The history of the origin of the squamules closely recalls that in the species already described. When the development of the first of these leaves is followed, however, it is found that there is a slight separation between the leaf and the shoot-axis in the median plane, at a level at which the flaps of the leaf-sheath are still attached to the flanks of the axis (Fig. 3 C). A band of squamular tissue (marked with a cross in Fig. $3 \mathrm{C}$ ) is thus left temporarily attached to the upper median region of the young leaf; but almost at once it becomes free on that side also (Fig. $3 \mathrm{D}$ ). II Fig. $3 \mathrm{E}$ the ligular sheath (lig. s.1 ) is completely detached from the petiole $\left(\right.$ pet. $\left._{1}\right)$. In this figure, also, we see the first indication of the separation of the leaf-sheath of the next leaf $\left(s h_{._{2}}\right)$ from the shoot-apex. Figs. $3 \mathrm{~F}$ and $\mathrm{G}$ show further stages in the development of this second leaf and the squamules within it $(s q . b)$. These squamules remain attached to the growing apex - in the median region marked with a cross in Fig. $3 \mathrm{~F}-$ even after the leaf has become completely free. 


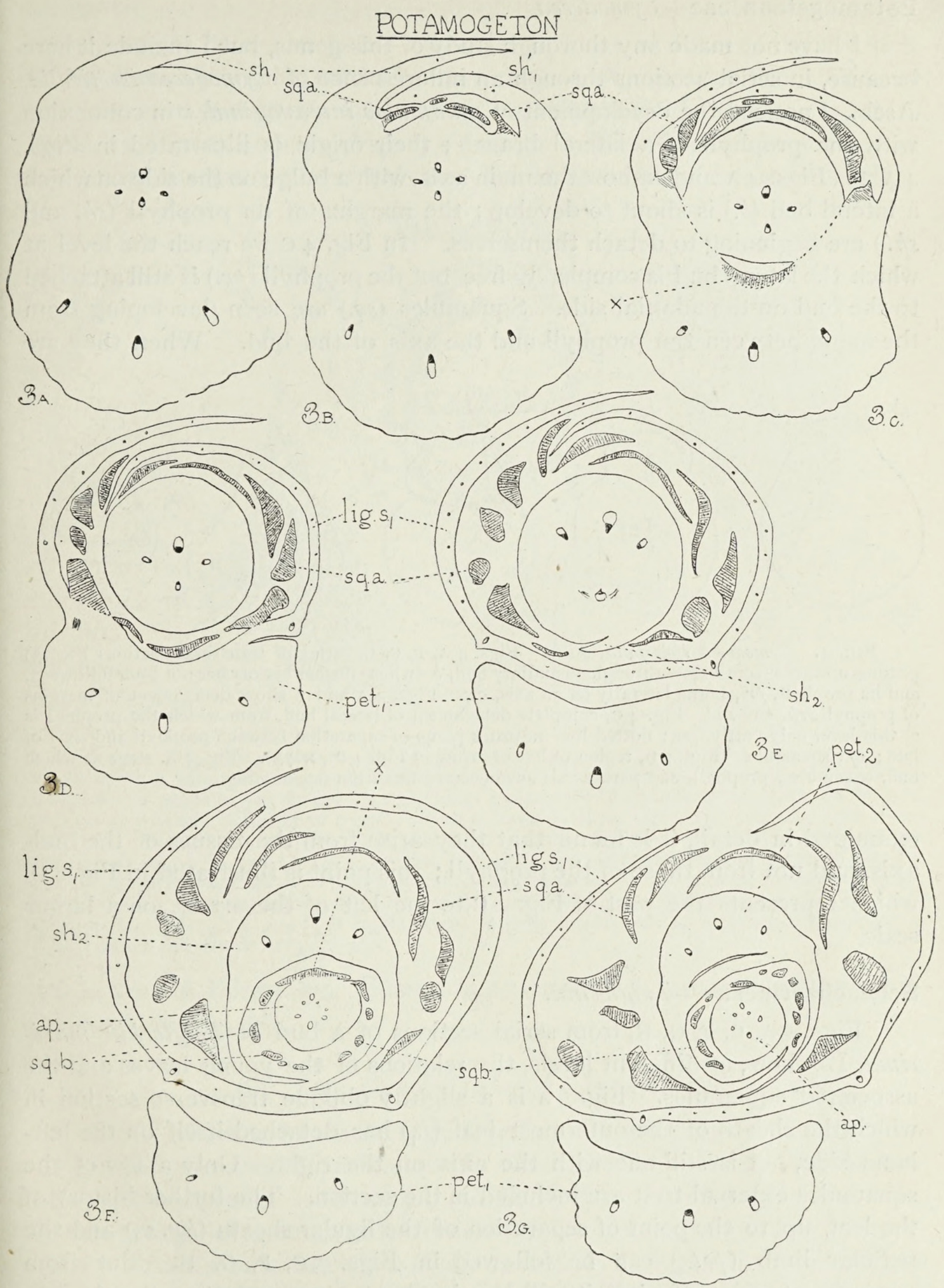

Fig. 3. Potamogeton natans, L. Figs. 3 A-E, series of transverse sections from below upwards through apical bud including two sticcessive leaves and the squamules within them $(\times 47)$; lettering as in Fig. I, see also explanation in text. Figs. $3 \mathrm{~F}$ and $\mathrm{G}$ show further stages in the development of the second leaf and the squamules. Fig. $3 \mathrm{~F}$, from a broken section, somewhat reconstructed as regards lig. $s_{._{1}}$ and $s q$. a on right. 


\section{Potamogetonaceae-Cymodocea.}

I have not made any thorough study of this genus, but I include it here because, in serial sections through an inflorescence of Cymodocea isoëtifolia, Asch., I noticed the development of squamulae intravaginales in connexion with the prophyll of a lateral branch; their origin is illustrated in Figs. $4 \mathrm{~A}-\mathrm{E}$. Figs. $4 \mathrm{~A}$ and $\mathrm{B}$ show the main axis, with a bulge on the side on which a lateral bud (b.) is about to develop; the margins of its prophyll (sh. and sh.') are beginning to detach themselves. In Fig. $4 \mathrm{C}$ we reach the level at which the lateral bud is completely free, but the prophyll ( $p r$.$) is still attached$ to the bud on the adaxial side. Squamules $(s q$.$) are seen developing from$ the angle between the prophyll and the axis of the bud. When they are
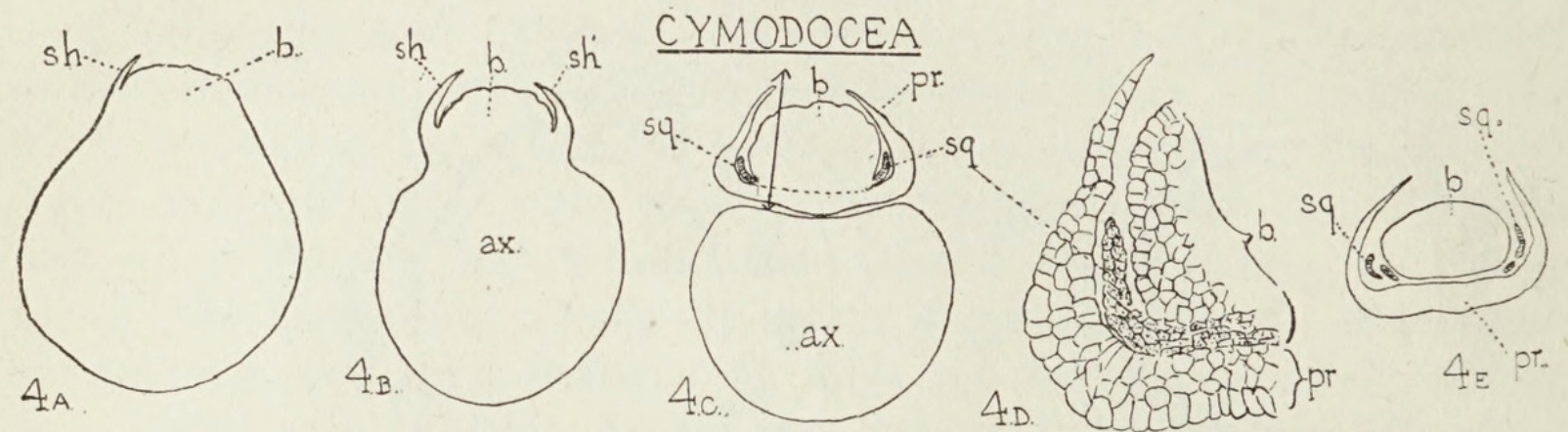

FIG. 4. Cymodocea isoëtifolia, Asch. Figs. 4 A, B, c, E, series of transverse sections $(\times 23)$ passing upwards from below through an axillary bud, $b$. (whose further history has not been followed), and its prophyll, pr., borne laterally on an axis, $a x$. Figs. $4 \mathrm{~A}$ and $\mathrm{B}$ show detachment of margins of prophyll, sh. and sh.' Fig. 4 C, complete detachment of lateral bud, from which the prophyll is at this level only partly free; dotted line indicates plane of separation between prophyll and axis of bud; sq., squamule. Fig. $4 \mathrm{D}$, region to left of arrow in Fig. $4 \mathrm{C}(\times 77)$. Fig. 4 E, stage at which bud, squamules, prophyll, and parent axis have become free from one another.

examined in detail, it is found that they arise from the tissues of the budaxis, and not from those of the prophyll; this point is illustrated in Fig. 4 D, which represents the part of Fig. $4 \mathrm{C}$ to the left of the arrow, on a larger scale.

\section{Scheuchzeriaceae-Triglochin.}

Figs. 5 A, C, F, G, H, from serial sections of a bud of Triglochin maritima, L., show, at different levels, the relations of the young leaves and the associated squamules. Fig. $5 \mathrm{~A}$ is a slightly oblique transverse section in which the sheath of the outermost leaf $\left(l_{\cdot_{1}}\right)$ has detached itself on the lefthand side, but is still one with the axis on the right. Only a few of the squamules external to it are included in the section. The further history of the leaf, up to the point of separation of the ligular sheath (lig.s..$_{1}$ ) and the petiolar limb $\left(\right.$ pet. $\left._{1}\right)$ can be followed in Figs. 5 C, F, G, H. But from our present point of view it will be simplest to concentrate attention on the second leaf and the squamules immediately outside it. In Fig. $5 \mathrm{C}$ this leaf $\left(l_{2}\right)$ is free on the left-hand side, but still fused with the young axis on the right. The leaf is surrounded by squamules, of which those 
on the left are free, whereas those on the right are attached to the external surface of the leaf, just below the level at which it divides from the axis. Of the three squamules marked with a cross in Fig. 5 C, the two right-hand ones are seen fused with one another and with the axis in Fig. 5 B, which is cut at a level between Figs. $5 \mathrm{~A}$ and $5 \mathrm{C}$. The structure of the young squamules, at the levels of freedom and of attachment, is shown in Figs.

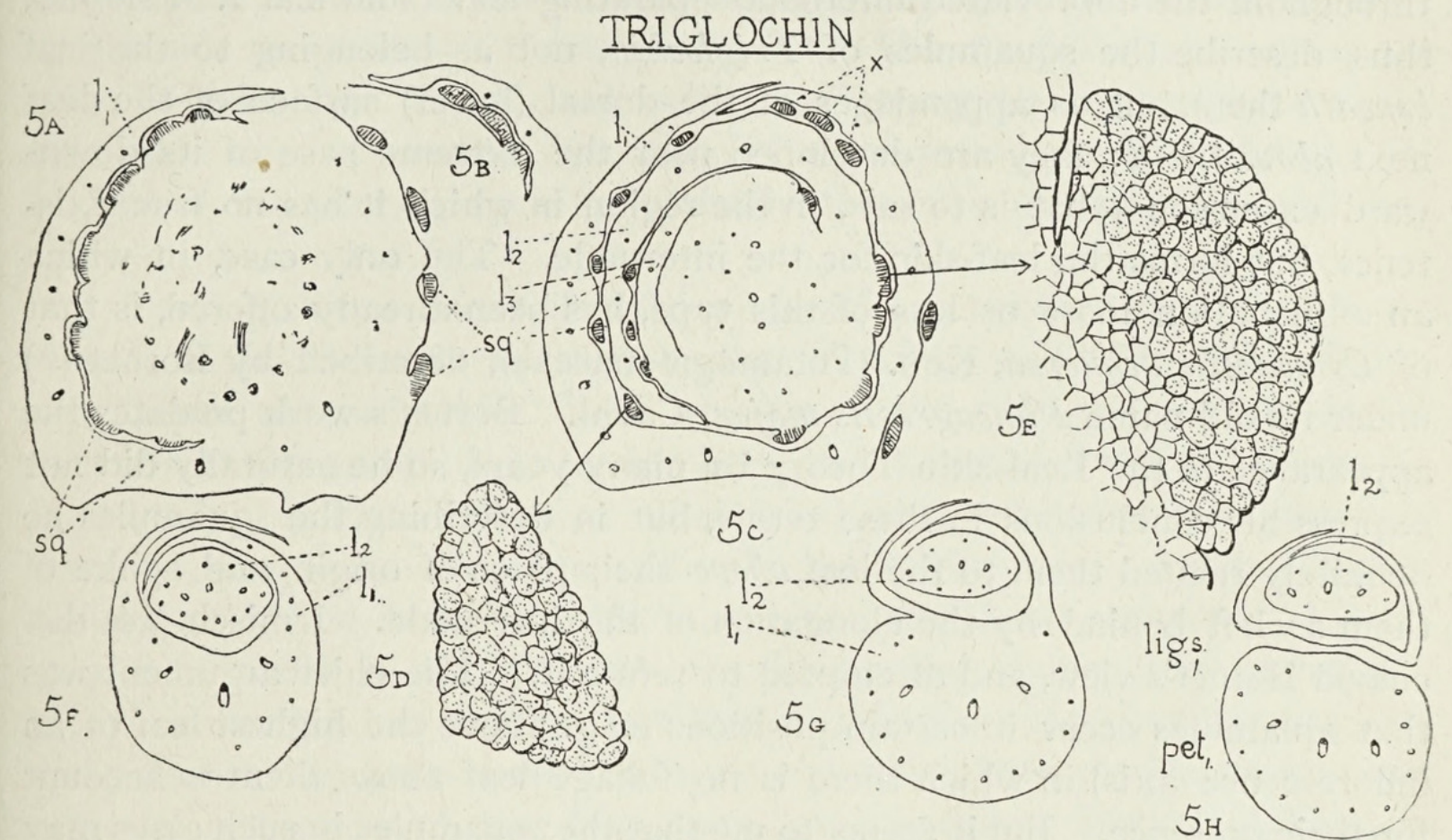

FIG. 5. Triglochin maritima, L. Figs. 5 A, B, C, F, G, H, serial transverse sections from below upwards through young leaf, $l_{\cdot 1}$, and the apical bud with younger leaves, $l_{\cdot 2}$ and $l_{\cdot 3}$, which it encloses; squamules, sq., shated $\left(x_{2} 3\right)$. Fig. $5 \mathrm{~A}$, margin of leaf-sheath of $l_{\cdot 1}$ free on left side, but, owing to slight obliquity of section, cut at a lower level on right-hand side, and there fused with axis. Fig. $5 \mathrm{C}$, section at a slightly higher level, showing three sets of squamules, external respectively to $l_{._{1}}, l_{._{2}}$, and $l_{.3}$. Fig. 5 B shows the three squamules marked with a cross in Fig. $5 \mathrm{C}$, cut at a slightly lower level. Fig. $5 \mathrm{D}$, detached squamule marked with arrow to left of Fig. 5 C ( $\times$ I93). Fig. $5 \mathrm{E}$, attached squamule marked with arrow to right of Fig. $5 \mathrm{C}\left(\mathrm{x}_{193}\right)$. Figs. $5 \mathrm{~F}$, G, H, sections through $l_{\cdot{ }_{1}}$ and $l_{._{2}}$ at higher levels, to show development up to point of separation of

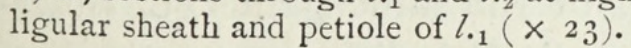

$5 \mathrm{D}$ and $\mathrm{E}$. A third set of squamules, external to $l_{\cdot 3}$, are visible on the lefthand side in Fig. 5 C.

(iii) The Origin of the Squamules.

Of the plants in which we have described the ontogeny of the squamules, Triglochin maritima, L., is the one in which the interpretation of the facts observed is open to least doubt. Irmisch (10) regarded the squamules in this genus, not as outgrowths from the leaves, but as originating independently from the axis, but more recent writers $(3,4,9)$ merely speak of them as arising in the leaf-axils. I think that the sections which $I$ have drawn in Figs. 5 A, B, C show conclusively that it was Irmisch who correctly seized the relation of the parts. But in the light of the 'Leaf-skin Theory', recently put forward by E. R. Saunders (19), I think that Irmisch's concep- 
tion needs restatement. If we interpret Fig. 5 A, p. 37, on Saunders's theory-which I adopt here because it appears to me to clarify our ideas of the spermophyte shoot-we should say that the surface of the 'axis' on the left-hand side (inside $l_{1_{1}}$ ), which is seen giving rise to squamules, is, in reality, the 'leaf-skin' belonging to leaf 2 ; this leaf-skin is regarded as extending downwards from the exsertion of leaf 2 , so that it clothes the axis throughout the abbreviated internode separating leaf I and leaf 2. I should, thus, describe the squamules of Triglochin, not as belonging to the leaf beneath them, but as appendages of the dorsal (lower) surface of the leaf next above them; they are developed near the extreme base of its downward extension - that is to say, in the region in which it has no free existence, but forms the leaf-skin for the internode. The only case, in which an explanation, more or less of this type, has been already offered, is that of Cymodocea aequorea, Kon. (Potamogetonaceae), described by Bornet (2) under its old name Phucagrostis major, Cavol. Bornet's work predates the appearance of the Leaf-skin Theory by many years, so he naturally did not express his conclusions in these terms, but in describing the squamules he definitely related them to the leaf above their place of origin, and spoke of them as left behind by the elongation of the internode. Irmisch (14) discussed Bornet's view, and attempted to refute it. His chief argument was that squamules occur in certain positions (e. g. above the highest leaf of an inflorescence axis) in which there is no foliage leaf above them to account for their presence. But it seems to me that the squamules in such cases may possibly be related to bracts or sepals occurring at some distance above them, for Saunders has brought forward evidence that modified leaves of this type may provide a downward prolongation of leaf-skin as effectively as if they were foliage leaves. Bornet's conclusions were based on a close and delicate examination of the squamules of Cymodocea aequorea, Kon., as solid objects. In the case of another species of the same genus ( $C$. isoëtifolia, Asch.) I have shown (p. 36), by the radically different method of serial sections, that it is possible to convince oneself that the squamules do not belong to the leaf in whose axil they are found, but arise from the apparent axis above this leaf (Fig. 4 D, p. $3^{6}$ ); this observation is thus confirmatory of Bornet's view.

In the other Potamogetonaceae which I have examined (Potamogeton natans and $P$. sp.) the squamules arise from a zone of tissue forming the boundary between the sheathing leaf-base and the 'axis' which it encloses. Whether this boundary tissue should be treated as belonging to this leaf or to the axis is, in this case, rather a subtle question. In the broad-leaved, submerged Potamogeton represented in Figs. I and 2, p. 33, there are clear indications that the squamules, on the side remote from the opening of the leaf-sheath, are still fused with the growing apex, after the leaf becomes detached from it. Examples of this attachment are seen in the squamules 
$(s q . d)$ inside the leaf $l_{{ }_{4}}$ in Fig. I C, and in the squamules inside the ligular sheaths of two successive leaves from another bud in Figs. $2 \mathrm{E}$ and G. In Potamogeton natans the same connexion with the 'axis' is seen in the case of the squamules marked with a cross inside the inner leaf $\left(s h_{._{2}}\right)$ in Fig. $3 \mathrm{~F}$. An exception, however, is illustrated in Fig. $3 \mathrm{C}$, for here the median band of tissue marked with a cross, which is destined to form a squamule, becomes detached from the growing apex before freeing itself on the side on which it adheres to the leaf. Despite this one exception, we may, I think, claim that the indications in Potamogeton are favourable to the view that the squamules, like those of Cymodocea, are derived from the surface of the growing apex immediately above the leaf in whose axil they appear to be located.

Leaving the cases which I have myself examined, and turning to the records in the literature relating to other Families, we find that the Hydrocharitaceae are the group about which we have most information on the question of the origin of the squamules. In the case of Stratiotes aloides, L., Nolte (16, p. 3, Plate I, Fig. 5) observed that, if the leaves were carefully removed, the squamules remained adhering to the axis. Again, although Solereder (22), in describing the squamules of Elodea canadensis, Michx., speaks of them as situated 'an der Blattbasis', Sanio (18), nearly half a century earlier, had pointed out that in this plant the development indicates that the squamules arise, without connexion with the leaves, from the external cell-layers of the stem apex. Furthermore, Bayley Balfour, in his beautiful memoir on Falophila (1), explicitly states that, in this genus, the squamules 'arise from the axis, and have no organic connection with the leaves'.

In the case of the A ponogetonaceae, the only knowledge we possess of the origin of the squamules is Serguéeff's statement (21) that they arise from the stem rather than the leaf. And in the Araceae, which, though not members of the Helobieae, show relationship with the Aponogetonaceae, Irmisch (14) found squamules occurring on the axis above the level of exsertion of each foliage leaf.

It seems to me that the indications met with in the literature, as well as the observations recorded in the present paper, agree in pointing to the conclusion that in the Scheuchzeriaceae, Potamogetonaceae, Aponogetonaceae, Hydrocharitaceae, and Araceae-that is to say, in all those Families in which we have any definite information about the origin of these structures-the squamulae intravaginales originate immediately above the leaf in whose axil they are found, and arise from the surface of the internode-that is to say, from the 'leaf-skin' belonging to the leaf whose point of exsertion lies next above them. It may be objected that, if this interpretation be correct, in seedlings of the Helobieae we ought to find squamules belonging to the cotyledon situated on the outer surface of the hypocotyl in its basal 
region. I am not aware that the existence of squamules in such a position has ever been recorded, but though their discovery at the junction of hypocotyl and radicle would be a strong confirmation of the views expressed in this paper, I do not think that these views are necessarily discredited by their absence. For in the exposed position which the 'collar' presents-unprotected by the leaf-sheaths which enclose the base of every other internode-the tendency to the formation of squamules may well be held in abeyance by the absence of the requisite physiological conditions.

If the squamules throughout the Helobieae are, as seems probable, dorsal basal appendages of the leaves, it becomes unnecessary to discuss the idea that they are stipulae intrafoliaceae (Caspary, 5), or the more recent suggestion that in the case of the Alismataceae they are ligular structures (Buchenau, 4). For neither stipules nor ligules are ever found on the dorsal surface of the leaves to which they belong. The case of the Alismataceae must, however, be treated as an open one for the present, since we have no exact information as to the origin of the squamules in this Family; it is, of course, probable that they arise in the same way as in the other Helobieae, but this cannot be assumed without proof. I have examined serial sections of buds of Sagittaria sagittifolia, L., from this point of view, but the thinness of the squamules, the extreme abbreviation of the internodes, and the crowding of the young leaves have, so far, prevented my arriving at any certainty as to the way in which the squamules originate.

\section{(iv) Summary.}

From a study of the origin of the squamulae intravaginales in Potamogeton and Cymodocea (Potamogetonaceae) and Triglochin (Scheuchzeriaceae), it is concluded that these structures are not appendages of the leaf in whose axil they are found-as has often been assumed-but that they originate from the surface of the internode separating this leaf from the next leaf above. The records in the literature indicate that this is also true for the Hydrocharitaceae, Aponogetonaceae, and those Araceae which possess squamules. In terms of the 'Leaf-skin Theory' of E. R. Saunders (19), the squamules should therefore be described as outgrowths from the downward, axis-clothing prolongation of that leaf whose level of exsertion comes next above their place of origin. 


\section{LIST OF REFERENCES.}

1. Balfour, I. B. (1879): On the Genus Halophila. Trans. and Proc. Bot. Soc. Edinburgh, vol. xiii, I 879 , pp. $290-343$, five plates.

2. Bornet, E. (1864): Recherches sur le Phucagrostis major, Cavol. Ann. d. sci. nat., sér. v, Bot., t. i., I 864 , pp. 5-5I, eleven plates.

3. Buchenau, F. (1882): Beiträge zur Kenntniss der Butomaceen, Alismaceen und Juncaginaceen. Engler's Bot. Jahrb., Bd. ii, I 882 , pp. $4^{6} 5^{-} 5^{10}$.

4. (1903): Scheuchzeriaceae, Alismataceae, Butomaceae, in Das Pflanzenreich (A. Engler), Bd. iv, pp. I4-I6. Leipzig, $190_{3} 3$, ninety-eight pages, thirty-three text-figures.

5. Caspary, R. (1858): Die Hydrilleen (Anacharideen Endl.). Pringsheim's Jahrb. f. wiss. Bot., Bd. i, I 858 , pp. $377^{-} 5$ I 3 , five plates.

6. Cunnington, H. M. (1912): Anatomy of Enhalus acoroides (Linn. f.) Zoll. Trans. Linn. Soc. Lond., Ser. II, Bot., vol. vii, I904-13, Part XVI, I9I 2, pp. $355^{-71}$, one plate, thirteen text-figures.

7. FAuth, A. (1903): Beiträge zur Anatomie und Biologie der Früchte und Samen einiger einheimischer Wasser- und Sumpfpflanzen. Beihefte zum Bot. Centralbl., Bd. xiv, I903, pp. 327-73, three plates.

8. Gibson, R. J. H. (1905): The Axillary Scales of Aquatic Monocotyledons. Journ. Linn. Soc., Bot., vol. xxxvii, I904-6, No. V, I905, pp. 228-37, two plates.

9. Hill, T. G. (1900): The Structure and Development of Triglochin maritimum, L. Ann. Bot., vol. xiv, I900, pp. 83-107, two plates.

10. Irmisch, T. (1858): Ueber das Vorkommen von schuppen- oder haarförmigen Gebilden innerhalb der Blattscheiden bei monokotylischen Gewächsen. Bot. Zeit., Jahrg. xvi, 1858 , pp. I $77-9$.

11. (1858): Ueber einige Arten aus der natïrlichen Pflanzenfamilie der Potameen. Berlin, 1858 , fifty-six pages, three plates.

12. (1859): Bemerkungen über einige Wassergewächse. Bot. Zeit., Jahrg. xvii, I859, pp. 353-6.

13. (1865): Beitrag zur Naturgeschichte des Stratiotes Aloides. Flora, N. R, Jahrg. xxiii, I865, pp. 8I-9I, one plate.

14. $(\mathbf{1 8 7 4})$ : Beiträge zur vergleichenden Morphologie der Pflanzen. Abt. V. Ueber einige Aroideen. Abhandl. d. Naturf. Gesellsch. zu Halle, Bd. xiii, Heft 2, pp. I6I-206, six plates.

15. Kirchner, O. von, Loew, E., and Schroeter, C. (1908) : Lebensgeschichte der Blïtenpflanzen Mitteleuropas. Helobieae, Bd. i, Abt. i, pp. 394-7I 4 , I95 text-figures.

16. Nolte, E. F. (1825): Botanische Bemerkungen über Stratiotes und Sagittaria. Kopenhagen, forty-four pages, two plates, 1825 .

17. Prillieux, E. (1864): Recherches sur la végétation et la structure de l'Althenia filiformis Petit. Ann. d. sci. nat., sér. v, Bot., t. ii, I864, pp. 169-9o, two plates.

18. Sanıo, S. (1865) : Einige Bemerkungen in Betreff meiner über Gefässbündelbildung geäuisserten Ansichten (Fortsetzung). Bot. Zeit., Jahrg. xxiii, 1865, pp. I84-7.

19. Saunders, E. R. (1922): The Leaf-skin Theory of the Stem. Ann. Bot., vol. xxxvi, pp. 135-65, thirty-four text-figures.

20. Schilling, A. J. (1894): Anatomisch-biologische Untersuchungen über die Schleimbildung der Wasserpflanzen. Flora, Bd. lxxviii, I894, pp. 280-36o, seventeen text-figures.

21. SeR̨gúfeff, M. (1907): Contribution à la morphologie et la biologie des Aponogétonacées. Université de Genève. Thèse ... docteur ès sciences, Institut de Botanique, $7^{\text {me }}$ sér., $8^{\text {me }}$ fasc., 1907, I 32 pages, five plates, seventy-eight text-figures.

22. Solereder, H. (1913): Systematisch-anatomische Untersuchungen des Blattes der Hydrocharitaceen. Beihefte zum Bot. Centralbl., Bd. xxx, Abth. I, I9I3, pp. 24-104, fifty-three text-figures. 


\section{$2 \mathrm{BHL}$ Biodiversity Heritage Library}

Arber, Agnes Robertson. 1923. "On the 'squamulae intravaginales' of the Helobieae." Annals of botany 37, 31-41.

https://doi.org/10.1093/oxfordjournals.aob.a089834.

View This Item Online: https://www.biodiversitylibrary.org/item/270686

DOI: https://doi.org/10.1093/oxfordjournals.aob.a089834

Permalink: https://www.biodiversitylibrary.org/partpdf/319065

\section{Holding Institution}

New York Botanical Garden, LuEsther T. Mertz Library

\section{Sponsored by}

BHL-SIL-FEDLINK

\section{Copyright \& Reuse}

Copyright Status: Public domain. The BHL considers that this work is no longer under copyright protection.

This document was created from content at the Biodiversity Heritage Library, the world's largest open access digital library for biodiversity literature and archives. Visit BHL at https://www.biodiversitylibrary.org. 